\title{
Odontogenic-related sepsis
}

Sir,

I read with great interest the recent research article on oral care practices for Intensive Care Unit (ICU) patients. ${ }^{[1]}$

I was pleased to read of the importance emphasized on dentists working with ICU for the holistic care of these vulnerable patients.

The article also briefly mentions how dentistry practice in hospitals aims to eliminate potential infection sources that can systemically affect patient recovery in critical care. Acute dental abscess is often polymicrobial in nature with various patient-host factors playing an important role in the pathogenesis of these odontogenic infections. ${ }^{[2]}$ Many of these risk factors are commonly found in critically ill patients and include acute kidney injury, diabetes, and hepatic cirrhosis.
Proper dental hygiene is well recognized across all medical fields to contribute to systemic inflammation and sepsis which the author does briefly mention. ${ }^{[3]}$ Other associated risks with poor dental hygiene in the critically ill should also be considered

For example, endocarditis is well regarded as a complication of poor oral hygiene seen. Bacteria originating from the mouth account for $35-45 \%$ of cases of infective endocarditis. ${ }^{[4]}$ Until recently, guidelines in the United Kingdom suggested prophylactic use of antimicrobials after dental surgery for at-risk patient groups. ${ }^{[5]}$

It is without question that patients in critical care settings have systemic multifactorial immunocompromise and could be considered at risk of developing infective vegetations on cardiac valve leaflets, and thus further emphasizes the need for thorough and routine oral hygiene.

I applaud the authors' conclusion that more education should be done on oral hygiene but suggest that this is multidisciplinary and not focused only on nursing 
staff. Dental sepsis can be life-threatening but can be prevented. ${ }^{[1]}$

\section{Financial support and sponsorship}

Nil.

\section{Conflicts of interest}

There are no conflicts of interest.

\section{Ryan Wereski $i^{1,2}$}

1Department of General Surgery, Glasgow Royal Infirmary, Glasgow, ${ }^{2}$ School of Medicine, University of Glasgow,

Scotland, UK

Correspondence:
Dr. Ryan Wereski,
Department of General Surgery, Glasgow Royal Infirmary,
Castle Street, Glasgow, Scotland, UK.
E-mail: wereski.ryan @ gmail.com

\section{References}

1. Miranda AF, de Paula RM, de Castro Piau CG, Costa PP, Bezerra AC. Oral care practices for patients in intensive care units: A pilot survey. Indian J Crit Care Med 2016;20:267-73.

2. Shweta S, Prakash SK. Dental abscess: A microbiological review. Dent Res J (Isfahan) 2013;10:585-91.

3. Li X, Kolltveit KM, Tronstad L, Olsen I. Systemic diseases caused by oral infection. Clin Microbiol Rev 2000;13:547-58.
4. Thornhill MH, Lockhart PB, Prendergast B, Chambers JB, Shanson D. NICE and antibiotic prophylaxis to prevent endocarditis. Br Dent J 2015;218:619-21.

5. National Institute for Health and Care Excellence. Prophylaxis against infective endocarditis: Antimicrobial prophylaxis against infective endocarditis in adults and children undergoing interventional procedures. NICE guideline (CG64). National Institute for Clinical Excellence; 2014.

This is an open access article distributed under the terms of the Creative Commons Attribution-NonCommercial-ShareAlike 3.0 License, which allows others to remix, tweak, and build upon the work non-commercially, as long as the author is credited and the new creations are licensed under the identical terms.

\begin{tabular}{|l|l|}
\hline \multicolumn{2}{|c|}{ Access this article online } \\
\hline Quick Response Code: & Website: \\
& www.ijccm.org \\
\cline { 2 - 2 } & DOI: 10.4103/0972-5229.186270 \\
\hline
\end{tabular}

How to cite this article: Wereski R. Odontogenic-related sepsis. Indian J Crit Care Med 2016;20:435-6. 